Marwah: Jurnal Perempuan, Agama dan Jender (p-ISSN: 1412-6095 | e-Issn: 2407-1587

Vol. 18, No. 1, 2019, Hal. 52-66

\title{
NILAI-NILAI GENDER DALAM PERSPEKTIF HISTORI PEWARISAN DARI ERA PRA ISLAM HINGGA ERA ISLAM
}

\author{
Muhammad Juni Beddu \\ STAI Ibnu Sina Batam, Kepulauan Riau, Indonesia \\ Jbuni_Cairo@yahoo.co.id
}

\begin{abstract}
This study aims to explore gender values in the perspective of inheritance history which is focused on pre-Islamic era to the Islamic era. The method used is the library research method. The results of the study show that the pre-Islamic inheritance system was very gender biased. Boys and girls who are immature and mature women are not entitled to inheritance. There is even a suggestion that a widow left behind by her husband can be inherited to the son. On the contrary, in the Islamic era, the gender bias in imberitance began to be eliminated. Women are entitled to inheritance, even when they are still in the womb of the mother. This is confirmed in al-Quran, surah an-Nisa verse 7. In line with time, the problem of comtemporaneous figh emerged in terms of inheritance with a gender perspective.
\end{abstract}

Keywords: Value; Gender; Inheritance History

\begin{abstract}
ABSTRAK
Penelitian ini bertujuan untuk mendalami nilai-nilai gender dalam perspektif histori pewarisan yang difokuskan pada era pra Islam hingga era Islam. Metode yang di gunakan dalam kaijian ini yaitu methode library reseach. Sebagai kontribusinya adalah memberikan informasi tentang sistem pewarisan era pra Islam, dimana anak laki-laki yang belum dewasa dan anak perempuan dan kaum perempuan tidak berhak mendapat warisan dari harta peninggalan. Mirisnya lagi, di era pra Islam orang beranggapan, bahwa janda dari orang yang meninggal juga dipandang warisan yang boleh berpindah tangan dari si ayah kepada anaknya. Setelah datang era Islam ketetapan hukumnya berbeda, pihak perempuan berhak mendapatkan warisan, bahkan sejak masih dalam kandungan, sebagaimana di tegaskan dalam surah An Nisaa ayat 7 , tanpa melihat gender. Sejalan dengan waktu maka bermunculan masalah figh kontemporer terutama dalam hal warisan tanpa melihat gender karena sudah menjadi ketetapan Allah SWT dalam Al Quran, termasuk kadar bagian-bagiannya.
\end{abstract}

Kata Kunci: Nilai; Gender; Histori Pewarisan

\section{PENDAHULUAN}

Pewarisan adalah salah satu cabang ilmu syar'i yang sangatlah urgen untuk dikaji, baik dari historinya maupun kontensnya, sebab ilmu ini telah di tegaskan oleh Rasulullah merupakan separuh dari ilmu keseluruhan. Walaupun demikian, terkadang bagi sebagian orang, tentang pewarisan ini yang paling cepat ditinggalkan, diabaikan, bahkan disepelekan. Akibatnya memunculkan berbagai fenomena dalam masyarakat yang menimbulkan kesenjangan, baik antara anak dengan ayah, anak dengan ibu atau 
antar sesama anak, dan lainnya. Dalam Al Quran Allah SW'T telah menegaskan sebagaimana yang terdapat dalam surah Al Fajr ayat 19 :

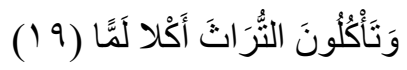

Dan kamu memakan harta pusaka dengan cara mencampur baurkan (yang halal dan yang bathil) (Qs Al Fajr :19)

Ayat di atas menegaskan bahwa adanya perintah Allah untuk berhati-hati terkait harta warisan untuk tidak mengambilnya dengan tidak benar dengan bentuk apapun. Dengan mendalami kajian pewarisan ini, kita bisa menambah pertahanan diri, keluarga bahkan masyarakat luas, untuk tidak mengambil harta warisan secara bathil, sebagaimana yang telah diatur dalam Islam.

Sekilas, pembagian warisan antara laki-laki dan perempuan yang disebutkan dalam Al quran, dalam perspektif gender terkesan tidak adil. Apalagi jika dikaji secara historis konsep pembagian harta warisan antara laki-laki dan perempuan sejak zaman pra Islam. Hal ini sejalan dengan perlakuan masyarakat pra Islam terhadap perempuan yang sangat berbeda dengan perlakuan mereka terhadap laki-laki. Status seorang perempuan dalam konteks sosial masyarakat pra Islam menempati posisi yang sangat rendah dibanding dengan status seorang laki-laki. Status seorang perempuan yang melahirkan seorang anak, hanyalah untuk tuannya, yaitu suaminya (Wahiduddin Khan, 414 H/ 1994 M). Pada undang-undang Rumani dijelaskan bahwa perempuan dipandang layaknya seorang bayi (anak kecil), ataupun seorang yang gila atau seseorang yang tidak mempunyai kecakapan untuk bertindak (Mutawalli Sya'rawi, t.t.).

Oleh karena itu, konsep gender, yang diartikan sebagai suatu konsep yang berupaya membuat perbedaan dalam hal peran, prilaku, dan mentalitas, dan karakteristik emosional antara laki-laki dan perempuan yang berkembang dalam masyarakat (Umar, 1999), sangat penting diperhatikan dalam memahami masalah pewarisan. Gender bukanlah perbedaan seksual antara laki-laki dan perempuan, tetapi gender adalah pembedaan laki-laki dan perempuan dilihat dari konstruksi sosial budaya (Showalter, 1989). Gender bisa juga dijadikan sebagai konsep analisis yang dapat digunakan untuk menjelaskan sesuatu (Umar, 1999). Lebih tegas lagi disebutkan dalam Women's Studies Encyclopedia, sebagaimana dikutip oleh Sofia 
(2018) bahwa gender adalah suatu konsep kultural yang dipakai untuk membedakan peran, perilaku, mentalitas, dan karakteristik emosional antara laki-laki dan perempuan yang berkembang dalam masyarakat (Sofia, 2018).

Untuk memahami konsep gender, maka harus dapat dibedakan antara kata gender dengan seks (jenis kelamin). Pengertian seks (jenis kelamin) merupakan pembagian dua jenis kelamin (penyifatan) manusia yang ditentukan secara biologis yang melekat pada jenis kelamin tertentu, dan tidak dapat berubah dan merupakan ketentuan biologis atau sering dikatakan sebagai kodrat (kehendak Tuhan) (Sofia, 2018). Oakley (1972) mengartikan gender sebagai konstruksi sosial atau atribut yang dikenakan pada manusia yang dibangun oleh kebudayaan manusia. Analisis gender dapat menemukan akar permasalahan yang melatarbelakangi masalah kesenjangan gender dan sekaligus dapat menemukan solusi yang tepat sasaran sesuai dengan tingkat permasalahannya.

Berdasarkan hal-hal di atas, sangat penting untuk mengkaji masalah pembagian warisan bagi laki-laki dan perempuan yang terkesan tidak adil gender, dalam perspektif historis. Permasalahan gender tidaklah bisa dipisahkan dengan kehidupan manusia, karena Allah SWT menciptakan manusia berpasang-pasangan, laki-laki dan perempuan, baik tua maupun muda, bahkan Allah SWT menciptakan jenis khuntsaa (jenis kelamin ganda), yang kesemuanya itu dalam konsep pewarisan Islam tetap mempunyai hak yang wajar, yang berbeda halnya dengan era sebelumnya.

\section{METODE}

Objek kajian ini adalah nilai-nilai dari pewarisan pada era pra Islam hingga era Islam sehingga dapat diketahui penetapan Islam dalam pewarisan terutama dalam hak perempuan dan anak-anak, yang termasuk di dalamnya para janda dalam penerimaan harta warisan.

Kajian ini berbentuk kualitatif yang melibatkan kajian kepustakaan, dengan metode pengumpulan data yang digunakan adalah analisis kandungan permasalahan, dengan menelaah artikel, buku dan lain-lain. Untuk memperkuat analisis, dilakukan wawancara dengan beberapa orang terkait permasalahan yang dibicarakan. Untuk memperoleh kajian mendalam tentang pewarisan era pra Islam hingga era Islam dilakukan analisis deskriptif yang sesuai dengan objek kajiannya. 


\section{HASIL DAN PEMBAHASAN}

\section{Nilai-nilai Warisan dalam Sejarah Pra Islam}

Keadaan seorang perempuan sebelum kedatangan masa Islam, kita dapat melihat qanun atau undang-undang Yunani, bahwa seorang perempuan layaknya seorang milik (barang) dari walinya. Dalam pandangan orang Yunani perempuan sebelum menikah merupakan milik dari ayahnya dan saudaranya. Jika perempuan telah menikah, dalam hukum orang Yunani kemilikannya berpindah dari tangan sebelumnya ke suaminya. Perempuan pada kalangan orang Yunani tidak punya hak independensi, baik sebelum menikah ataupun sebelum menikah termasuk dalam hal pewarisan.

Ketidakberpihakan hukum pewarisan terhadap perempuan juga dapat dilihat pada undang-undang yang berlaku di kalangan orang Romawi. Pada undang-undang Rumani dijelaskan bahwa perempuan dipandang layaknya seorang bayi (anak kecil), ataupun seorang yang gila atau seseorang yang tidak mempunyai kecakapan untuk bertindak. Perempuan pada undang-undangnya digambarkan tetap di bawah pantauan walinya semata baik ayahnya ataupun suaminya (Mutawalli Sya'rawi, t.t.). Demikian juga filsafat orang Persia bahwa mereka beranggapan lebih afdhal seorang laki-laki menikahi ibunya, atau anak perempuanya ataupun saudaranya (Al Bouty, 1398 H-1987M).

Wahiduddin Khan dalam bukunya "Al Mar'atul baina Syariatil Islami Wal Hadhararatil Gharbiyah" menulis bahwa bahwa status seorang peempuan dalam konteks sosial masyarakat dulu (qadim), dimana mereka menempati posisi atau status yang sangat rendah dibanding dengan status seorang laki-laki, bahkan beliau memandang bahwa status seorang perempuan yang melahirkan seorang anak, hanyalah untuk tuannya yaitu suaminya (Wahiduddin Khan, 1414 H/ 1994 M).

Ketidakberpihakan hukum pewarisan terhadap perempuan juga dapat dilihat dari sejarah orang Arab yang disebut dengan orang-orang Arab Jahiliyah. Orang Arab jahiliah adalah salah satu bangsa yang gemar mengembara, beternak, berdagang dan senang berperang. Kehidupan mereka banyak bergantung kepada hasil rampasan perang dari bangsa-bangsa atau suku-suku yang telah mereka taklukkan selain budaya mereka yang gemar berdagang. Di antara yang mereka perdagangkan adalah rempah- 
rempah, dan lain-lain hingga ke negeri Syam. Hal ini dapat dilihat dari surah Quraisy ayat $1-2$ :

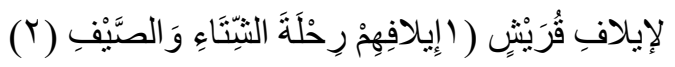

Karena kebiasaan orang-orang Quraisy,(yaitu) kebiasaan mereka bepergian pada musim dingin dan musim panas (Qs Qurays: 1-2)

Ayat di atas dapat dipahami bahwa orang Quraisy biasa mengadakan perjalanan terutama untuk berdagang ke negeri Syam pada musim panas dan ke negeri Yaman pada musim dingin. dalam perjalanan itu mereka mendapat jaminan keamanan dari penguasa-penguasa dari negeri-negeri yang dilaluinya. ini adalah suatu nikmat yang Amat besar dari Tuhan mereka. oleh karena itu sewajarnyalah mereka menyembah Allah yang telah memberikan nikmat itu kepada mereka.

Dalam hal pembagian harta warisan mereka berpegang teguh kepada adat istiadat yang telah diwariskan oleh nenek moyangnya. Menurut ketentuan yang telah berlaku, bahwa anak yang belum dewasa dan anak perempuan atau kaum perempuan tidak berhak mendapat warisan dari harta peninggalan orang yang meninggal dunia. Tidak hanya itu, mereka beranggapan bahwa janda dari orang yang meninggal, dianggap sebagai warisan dan boleh berpindah tangan dari si ayah kepada anaknya atau ke yang lainnya. Secara garis besar, yang menjadi sebab pusaka mempusakai pada masa Jahiliyyah ada tiga macam, di antaranya: Adanya pertalian kerabat (القرابة). Pertalian kekerabatan belum dianggap memadai untuk mendapat warisan dan yang paling penting adalah adalah gender laki-laki (yang dewasa) karena kuat jasmani untuk berperang atau membela dan mempertahankan keluarga maupun kabilah (suku) dari serangan pihak lain, gender perempuan tidaklah dianggap dalam pewarisan, karena tidak sekuat dengan laki-laki untuk melindungi, mengayomi, dan mempertahankan baik keluarga ataupun kabilah.

Dengan demikian, para ahli waris pada zaman Jahiliyyah dari golongan kerabat terdiri dari anak laki-laki, saudara laki-laki, paman, anak laki-laki paman (Lajnah Jamiatul Azhar, 2015). Dalam pembagian warisan (harta pusaka), mereka menganut sisetm yang ditinggalkan oleh leluhur mereka.Anak-anak kecil dan perempuan Arab Jahiliyah tidak berhak memperoleh harta warisan. Ironisnya lagi, di antara mereka ada yang beranggapan bahwa janda perempuan dari seseorang yang meninggal, dapat di wariskan kepada ahli waris suaminya (M. Bakry, 2015). 


\section{NILAI-NILAI PEWARISAN PADA ERA ISLAM}

Adanya beberapa nilai terkait aturan pewarisan pada era pra Islam sebagaimana yang telah digambarkan sebelumnya yang tidak berpihak pada perempuan, anak-anak dan lainnya, datangnya Islam, di eranya aturan-aturan itu telah dibatalkan dengan adanya beberapa penjelasan baik melalui Al Quran maupun melalui Hadis. Di antara aturan yang dijelaskan dalam Islam menegaskan bahwa perempuan dan anak kecil mengambil haknya(Mutawalli Sya'rawi), sebagaimana dalam surah An Nisaa ayat 7.

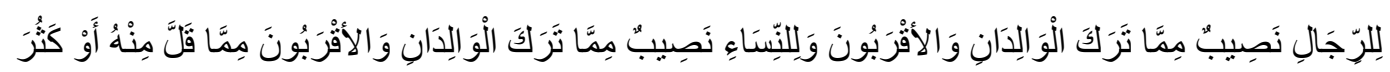

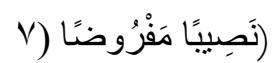

Bagi orang laki-laki ada hak bagian dari harta peninggalan ibu-bapa dan kerabatnya, dan bagi orang wanita ada hak bagian (pula) dari harta peninggalan ibu-bapa dan kerabatnya, baik sedikit atau banyak menurut bahagian yang telah ditetapkan. (Qs An Nisaa: 7).

Demikian Firman Allah SWT dalam Al-Quran Surat An Nisaa: 11. Allah juga menegaskan hak anak laki-laki dan perempuan sebagai berikut :,

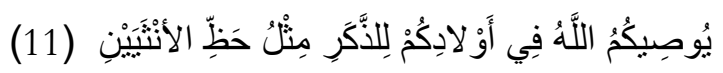

Allah mensyariatkan bagimu tentang (pembagian pusaka untuk) anak-anakmu. Yaitu : bahagian seorang anak lelaki sama dengan bagahian dua orang anak perempuan (Qs An Nisaa: 11).

Selain itu, dalam Islam juga ditetapkan bahwa orang-orang yang mempunyai ikatan janji prasetia dengan si mati berhak mendapatkan seperempat harta peninggalannya. Janji prasetia tersebut baru terjadi dan mempunyai kekuatan hukum, apabila kedua belah pihak telah mengadakan ijab-qabul dan janji prasetianya. Ucapan (sumpah) yang bisa digunakan, antara lain:

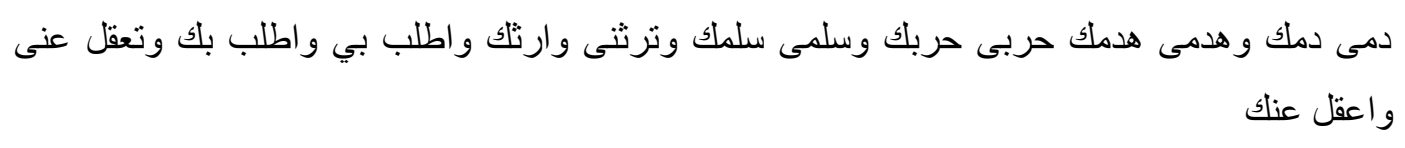

Artinya "Darabku darabmu, pertumpahan darabku pertumpahan darabmu, kamu mewarisi hartaku aku pun mewarisi hartamu, kamu dituntut darahmu karena tindakanmu terhadapku aku pun dituntut darabku karena tindakanku terhadapmu dan kamu di wajibkan membayar denda sebagai pengganti nyawaku akupun di wajibkan membayar denda sebagai pengganti dari nyawamu". 
Hak pewarisan juga ditetapkan dalam Islam terhadap anak yang diadopsi oleh seseorang. Pengangkatan anak (adopsi) dapat dilihat dari dua sisi yaitu menggabungkan seorang anak kepadanya sebagai anak secara shahih, meskipun di ketahui bahwa anak tersebut anak orang lain, hingga hak-haknya pun juga lebih jelas. Demikian juga adopsi yaitu menjadikan seseorang yang bukan anaknya seperti anaknya sendiri dalam urusan pengawasan dan pendidikan, tanpa mengikutkan nasabnya dan tidak seperti anak, yang terakhir ini merupakan suatu perbuatan yang terhormat dan kebaikan seperti menjaga atau mengurus anak takut hilang karena orang tuanya telah wafat, atau karena kedua orang tuanya tiada ataupun karena kafakiran, hal ini tidaklah terlarang secara syari'at, bahkan hukumnya mandub (sunnah), karena bagian dari bab rahmah dan saling membantu.

Adopsi yang pertama di atas merupakan adat kebiasaan yang berlaku dalam masyarakat Arab Jahiliyah, walaupun anak tersebut jelas mempunyai orang tua sendiri. Anak yang diangkat mempunyai hak-hak yang sama dengan hak-hak anak kandung, baik dari nasab maupun warisan (Athiyyah Shaqr, 2002). Pada suatu hari di masa Rasulullah Saw pernah terjadi ketika Zaid bin Haritsah di culik dari keluarganya, lalu di jual sebagai budak. Kemudian iadibeli oleh Hakim bin Huzam. Lalu ia diambil oleh Sayyidatina Khadijah Ra, dan menghibahkannya kepada Muhammad Rasulullah Saw. Maka Zaid bin Haritsah menjadi hamba sahaya Rasulullah Saw. Ketika keluarga Zaid mengetahui anaknya berada di Mekkah, lalu ketemu bersama dengan Rasulullah Saw, Rasulullah tidak serta merta memberikan anak itu kepada keluarganya tapi ia di beri pilihan "ikut keluarga atau tetap bersama Rasulullah". Ternyata Zaid tetap memilih untuk bersama Rasulullah saw, sehingga Rasulullah memuliakan Zaid sehingga ia memberi nama dengan nasab sesuai yang berkembang pada bangsa Arab yaitu Zaid bin Muhammad, dan terjadilah tabnnahu (mengangkat anak) (Mutawalli Sya'rawi, t.t.). Terkait kejadian itu, Allahpun membimbing Rasul, dengan melarang menetapkan pada nama Zaid bin Muhammad karena ia bukan anaknya Nabi. Terkait kejadian itu, ayat Al-Quranya adalah:

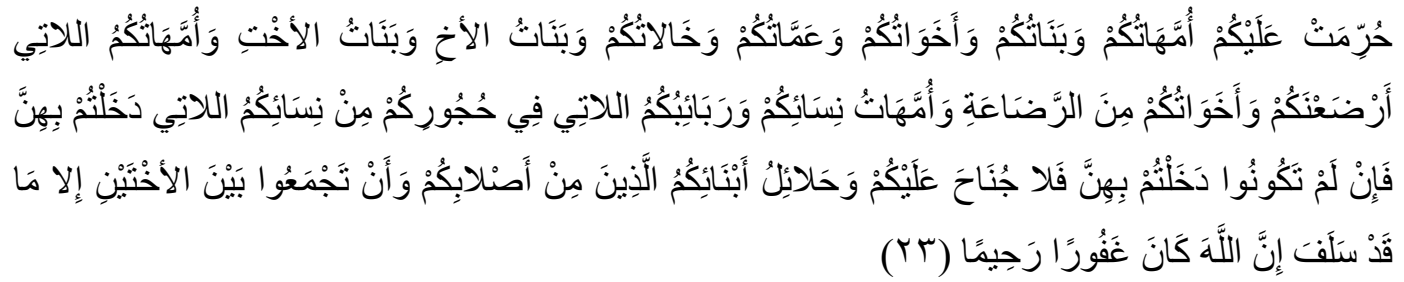


Diharamkan atas kamu (mengawini) ibu-ibumu; anak-anakmu yang perempuan; saudarasaudaramu yang perempuan, saudara-saudara bapakmu yang perempuan; saudara-saudara ibumu yang perempuan; anak-anak perempuan dari saudara-saudaramu yang laki-laki; anak-anak perempuan dari saudara-saudaramu yang perempuan; ibu-ibumu yang menyusui kamu; saudara perempuan sepersusuan; ibu-ibu isterimu (mertua); anak-anak isterimu yang dalam pemelibaraanmu dari isteri yang telah kamu campuri, tetapi jika kamu belum campur dengan isterimu itu (dan sudah kamu ceraikan), Maka tidak berdosa kamu mengawininya; (dan diharamkan bagimu) isteri-isteri anak kandungmu (menantu); dan mengbimpunkan (dalam perkawinan) dua perempuan yang bersaudara, kecuali yang telah terjadi pada masa lampau; Sesunggubnya Allab Maha Pengampun lagi Maha Penyayang (Qs An Nisaa 23).

Kalimat "anak kandugnmu" pada ayat di atas dapat dipahami bahwa kalimat ini yang menunjukkan bahwa terdapat anak bukan dari anak kandung yaitu anak adopsi. Allah SWT bermaksud untuk melarang (mengharamkan) adopsi yang merupakan adat yang sudah berkembang di kalangan bangsa Arab Jahiliyah, maka Rasulullah Saw membatalkannya (Mutawalli Sya'rawi, t.t. ).

Orang yang telah diadopsi (diangkat anak) oleh si mati berhak mendapatkan harta peninggalannya seperti anak keturunan si mati. Dalam segala hal, ia dianggap serta diperlakukan sebagai anak kandung dan dinasabkan kepada ayah angkatnya, bukan kepada ayah kandungnya. Di kalangan jahiliyah bahwa sistem adopsi ini menjadikan salah satu larangan pernikahan, yaitu di haramkan terhadap anak adopsi menikahi ibu yang mengadopsinya, meskipun ia dalam keadaan muthallaqah (tertalak), sebagaimana diharamkannya anak kandung perempuan yang mengadopsinya (Lajnah Jamiatul Azhar, 2015).

Dengan turunya Al Quran surat Al ahdzab ayat 4-5 yang cakupannya pembatalan anak angkat, maka kita dapat pahami bahwa anak angkat meskipun sudah dianggap sebagai anak sendiri, ia tetap hukumnya sebagai orang lain, tidak menjadi mahram dan tidak pula dapat mewarisi, harta orang tua angkat tetap hak ahli warisnya secara nasab, walaupun ia ada peluang mendapatkan harta warisan, di antaranya melaui wasiat dari orang tua angkatnya (Sulaiman Rasjid, 2014).

Pada masa awal Islam, kekuatan kaum muslimin masih sangat lemah, lantaran jumlah mereka sedikit. Untuk menghadapi kaum musyrikin Quraisy yang sangat kuat, Rasulullah saw. meminta bantuan penduduk di luar kota Mekkah yang sepaham dan simpatik terhadap perjuangannya dalam memberantas kemusyrikan.Adapun yang menjadi sebab pusaka mempusakai (pewarisan) pada masa awal Islam ada beberapa 
macam:Adanya pertalian kerabat (القرابة), adanya pengangkatan anak (التبني), adanya Hijrah (dari Mekkah ke Madinah), persaudaraan antara kaum Muhajirin dan Anshar (الهجرةالمؤخة و).

Melihat perkembangan ini, dapatlah di katakan bahwa Islam telah memerdekakan perempuan dan telah memberikan hak-haknya. Islamlah yang pertama membuka jalan kepada perempuan untuk mendapatkan hak-haknya secara penuh, meskipun pada masyarakat sosial lainya belum sedemikian rupa (Wahiduddin Khan, 1994).

Setelah aqidah umat Islam bertambah kuat, dan satu sama lain diantara mereka telah terpupuk rasa saling mencintai, dan kecintaan mereka kepada Rasulullah saw. sudah sangat melekat, yang menyebabkan perkembangan Islam makin maju. Pengikut-pengikut bertambah banyak, pemerintahan Islam sudah stabil, maka sebabsebab pewarisan yang hanya berdasarkan gender laki-laki yang dewasa dan mengenyampingkan anak-anak dan kaum perempuan, sebagaimana yang dilakukan oleh orang-orang Jahiliyah telah dibatalkan oleh firman Allah swt:

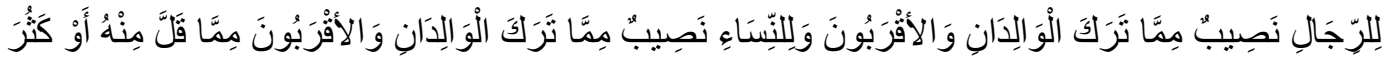

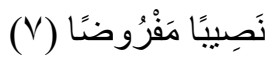

Bagi orang laki-laki ada hak bagian dari harta peninggalan ibu-bapa dan kerabatnya, dan bagi orang wanita ada hak bagian (pula) dari harta peninggalan ibu-bapa dan kerabatnya, baik sedikit atau banyak menurut bahagian yang telab ditetapkan.(Qs An Nisaa: 7)

Demikian juga sebab pewaris yang berdasarkan janji prasetia, Allah SWT membatalkan odengan firmanNya dalam Qs An Nisaa 33 sebagai berikut:

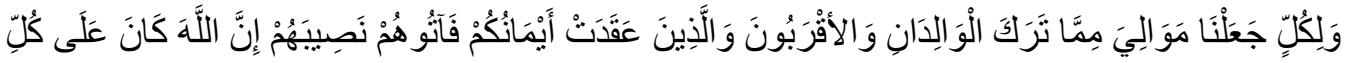

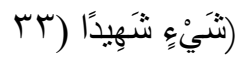

Bagi tiap-tiap harta peninggalan dari harta yang ditinggalkan ibu bapak dan karib kerabat, Kami jadikan pewaris-pewarisnya. dan (jika ada) orang-orang yang kamu telah bersumpah setia dengan mereka, Maka berilah kepada mereka bahagiannya. Sesunggubnya Allah menyaksikan segala sesuatu.(Qs An Nisa 33).

Pewarisan yang berdasarkan adanya pengangkatan anak (adopsi) dibatalkan oleh firman Allah: 


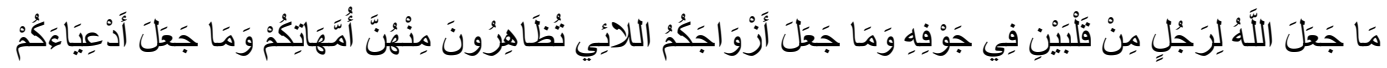

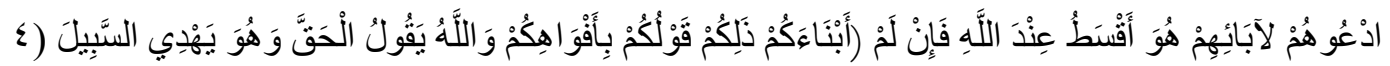

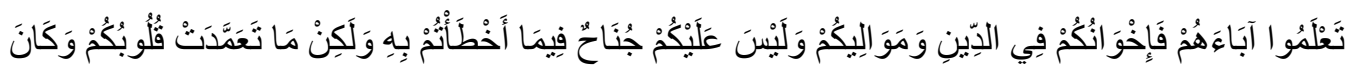

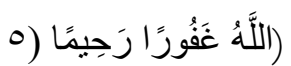

Allah sekali-kali tidak menjadikan bagi seseorang dua buah hati dalam rongganya; dan Dia tidak menjadikan istri-istrimu yang kamu zhihar, itu sebagai ibumu, dan Dia tidak menjadikan anak-anak angkatmu sebagai anak kandungmu (sendiri) yang demikian itu banyalah perkataanmu dimulutmu saja dan Allab mengatakan yang sebenarnya dan Dia menunjukekan jalan (yang benar). Panggilah mereka (anak-anak angkat itu) dengan (memakai) nama bapakbapak mereka; Itulah yang lebih adil pada sisi Allah, dan jika kamu tidak mengetabui bapakbapak mereka, Maka (panggilah mereka sebagai) saudara-saudaramu seagama dan maulamaulamu,.dan tidak ada dosa atasmu terbadap apa yang kamu kbilaf padanya, tetapi (yang ada dosanya) apa yang disengaja oleh hatimu. dan adalah Allab Maha Pengampun lagi Maha Penyayang.(Q.S al-Ahzab :4-5)

Dari uraian diatas, dapatlah dipahami dalam aturan pewarisan Islam, bahwa yang berhak menerima harta warisan tidak terbatas kepada kaum laki-laki yang sudah dewasa saja, melainkan anak-anak laki-laki, anak perempuan, semuanya berhak mendapatkan haknya dalam pewarisan sesuai ketentuan Allah SWT yang sudah di tentukan dalam Al Qur'an. Dalam pewarisan Islam tidak dikenal adanya janji prasetia sebagaimana yang berlaku di awal hijrah Rasulullah Saw. Demikian juga pengangkatan anak (adopsi) aturan pewarisan Ilsam telah menghapusnya.Maka dengan memberlakukan hukum Islam dalam pewarisan maka hukum adat atau kebiasaan masa Jahiliyah, di anggap mansukh (terhapus) tidak berlaku lagi.

Dan telah menjadi ketetapan para fuqaha bahwa laki-laki dan perempuan ataupun seorang janda yang meninggal suaminya, mereka berhak mendapatkan warisan, bahkan anak yang masih dalam kandungan pun sudah wajib di hitung dan di hargai secara muqaddarah (apakah ia seorang laki-laki atau seorang perempuan yang akan lahir) (Sulaiman Rasjid, 2014). Maksud masih dalam kandungan pun tetap di hargai dan di berik haknya, contohnya seorang ibu hamil mendapatkan rukhsah untuk berbuka karena janinya, demikian anak yang sudah lahir tapi masih menyusui juga di berikan rukhsah untuk berbuka karena anak menyusui (Umar Hasyim, 1334 H-2013 M), demikian dalam hal warisan mereka wajib mendapatkan haknya tanpa membedakan gendernya. 
Dalam Islam, jika seseorang terlahir dengan gender laki-laki maka ia mendapatkan haknya sebagai laki-laki, jika seseorang terlahir dalam gender perempuan maka ia mendapatkan haknya sebagai gender perempuan. Dan jika seseorang terlahir sebagai gender ganda, ia tetap mendapatkan haknya setelah jelas jenis kelamin yang paling dominan gendernya setelah ia baligh (Athoillah, 2013). Dalam Islam, jika seorang khuntsa dihukumi sebagai laki-laki, maka ia akan mendapatkan haknya sebagai hak waris laki-laki, dan jika ia di hukumi sebagai perempuan maka ia mendapatkan hak waris perempuan. Yang sulit ketetapan hukumnya dalam warisan adalah jika alat kelaminnya belum bisa diputuskan, maka ada hitungan waris tersendiri (Saifuddin, 2016).

Dari paparan di atas dapat dipahami bahwa di antara sebab-sebab yang ditetapkan oleh Fuqaha untuk mendapatkan warisan yaitu :

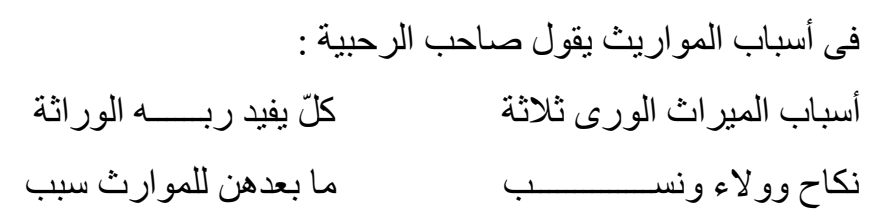

Dari kitab Matan Rahbiyah di atas dapat di pahami bahwa sebab mendapatkan warisan dapat dikelompokkan mejadi 3, akan tetapi penulis menyusunya sesuai dengan porsi kekuatan warisan tersebut, di antaranya:

Abli Waris karena Hubungan Keturunan (النسب) atau Kekerabatan (القرابة)

Ahli waris yang pertalian kekerabatannya kepada muwaris berdasarkan hubungan darah. Yaitu hubungan nasab yang memunculkan antara pewaris dan ahli waris, salah satu sebab yang paling kuat dalam waris. Ahli waris nasabiyah ini terdiri dari 15 orang laki-laki dan 10 orang perempuan, seluruhnya 25 orang. Dari Ahli waris nasabiyah tersebut di atas, apabila dikelompokkan menurut tingkatan kekerabatannya adalah sebagai berikut: (1) Furu al-waris, yaitu ahli waris anak keturunan si mati, atau tersebut kelompok cabang (al-bunuwwah). Kelompok inilah yang terdekat, dan mereka yang didahulukan menerima warisan. Ahli waris kelompok ini adalah: anak perempuan, cucu perempuan garis laki-laki, anak laki-laki dan cucu laki-laki garis laki-laki. (2) Ushul al-waris, yaitu ahli waris leluhur si mati. Kedudukannya berada setelah kelompok furu'al-waris. Mereka adalah: bapak, ibu kakek garis bapak, kakek garis ibu, nenek garis ibu dan nenek garis bapak. (3) Al-Hawasy, yaitu ahli waris 
kelompok saudara termasuk di dalamnya paman dan keturunannya seluruhnya ada 12 orang, yaitu: saudara perempuan se-kandung, saudara perempuan se-ayah, saudara perempuan seibu, saudara laki-laki se-kandung, saudara laki-laki se-ayah, saudara laki-laki seibu, anak saudara laki-laki se-kandung, maka saudara laki-laki seayah, paman se-kandung, paman se-ayah, anak paman se-kandung dan anak paman se-ayah.

Dari konsep nasab yang ada diatas dapat kita pahami bahwa Islam mendudukan semua nasab baik yang dari Ushul waris, furu'waris dan hawasy tanpa ada perbedaan gender. Demikian juga Islam telah mendudukkan semua posisi semua anak baik yang dewasa atau bahkan yang masih dalam kandungan, kaum perempuan, bersamaan dengan orang tua pewaris sebagai status ahli waris (Faqih, 2017).

Selanjutnya ahli waris yang berhubungan pewarisannya timbul karena hubungan perkawinan yaitu perkawinan yang di lakukan atas akad yang sah,yaitu istri yang sudah di campuri. Apabila meninggal salah satunya baik suami ataupun istri, maka ia tetap saling mewarisi, hingga batas sebelum berakhir idahnya ketika ia terthalaq.Adapun bila terjadi thalaq sebelum di campuri maka tidak saling mewarisi dan tidak ada hitungan idah, sebagaimana Firman Allah SWT dalam Qs Al Ahzab : 49.

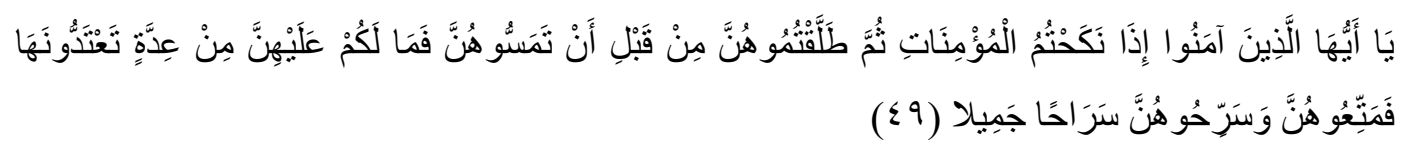

Hai orang-orang yang beriman, apabila kamu menikabi perempuan-perempuan yang beriman, kemudian kamu ceraikan mereka sebelum kamu mencampurinya Maka sekali-sekali tidak wajib atas mereka 'idab bagimu yang kamu minta menyempurnakannya. Maka berilah mereka mut'ab dan lepaskanlah mereka itu dengan cara yang sebaik-baiknya.(Qs Al Ahzab : 49)

Adapun bila terjadi thalaq setelah di campuri maka saling mewarisi selama masih dalam keadaan idah, akan tetapi kalau ia sudah habis dari masa idahnya, maka tidak saling mewarisi lagi. Fuqahaa mensyaratkan pernikahan salah satu sebab tejadinya hubungan warisan yaitu hubungan pernikahan yang sah, maka tidak termasuk di dalamnya pernikahan yang fasid (tidak sah), seperti seorang menikahi saudari susuannya, yang ia tidak ketahui kecuali setelah terjadi percampuran suami isteri, maka hubungan pernikahannya otomatis harus di fasakh tanpa thalaq, sehingga tidak terjadi hubungan waris (Bakri Ismail: 1418 H/1997): 
Dalam Islam juga diatur bahwa bila tejadi pernikahan yang tidak memenuhi syarat syar'i yaitu tidak lengkap rukun dan syaratnya maka di anggap tidak berhak mendapatkan warisan, karena tidak tercapainya rukun dan syarat pernikahan tersebut. Misalnya seseorang kumpul kebo, sehingga ia menikah tanpa memenuhi rukun dan syaratnya maka di anggap tidak berhak mendapatkan warisan. Atau semisal dengan anak yang terlahir di luar pernikahan, maka anak yang terlahir di luar pernikahan tanpa membedakan gender, baik ia laki-laki ataupun perempuan maka tidak berhak untuk mewarisi. Contohnya ketika sang laki-laki (ayah yang melakukan zina) yang duluan meninggal dunia, maka anak yang terlahir tidak berhak mendapatkan warisan, demikian juga andaikan anak yang terlahir di luar nikah duluan meninggal dunia, maka sang laki-laki (ayah yang melakukan zina) juga tidak berhak mendapatkan warisan dari anak yang terlahir di luar nikah, bahkan untuk menjadi wali pernikahan pun juga tidak sah menjadi wali, karena tidak ada hubungan darah secara syar'i.

Dari gambaran di atas menurut Dominikus Rato dalam bukunya Hukum Perkawinan dan waris Adat di Indonesia bahwa anak laur nikah secara hukum hanya menpunyai hubungan dengan ibu kandungnya, sedangkan terhadap ayahnya ia hanya mempunyai hubungan biologis, psikhologis, dan sosial, tidak ada akibat hukum terutama yang berkaitan dengan ahli waris (Dominikus: 2015).

Dalam Islam juga diakui bahwa, seseorang dipandanng sebagai ahli waris yang hubungan pewarisnya timbul karena memerdekakan hamba sahaya. Barang siapa yang memerdekakan hamba sahaya, kemudian hamba sahaya meninggal dan ia mempunyai harta peninggalan maka yang memerdekakan punya hak terhadap harta tersebut dengan syarat, hamba sahaya tersebut tidak memilki pewaris yang lebih kuat seperti suami /isteri atau pun kerabat (Bakri Ismail: 1418 H/1997). Asal usul sebab warisan sebab ini sebagaimana dalam hadits Bukhari dan Muslim yang berbunyi :

$$
\text { أن رسول الله صهم قال :( إنما الو لاء لمن أعتق ) }
$$

Artinya : Bahwasannya Rasulullah Saw bersabda: Sesunggubnya Al Wala bagi yang memerdekakan.

\section{SIMPULAN}


Dari pemaparan di atas dapat disimpulkan bahwa pada era pra Islam nilai-nilai pewarisan terhadap perempuan termasuk terhadap anak-anak yang seharusnya berhak mendapatkan warisan, sangatlah menyedihkan karena menurut ketentuan yang telah berlaku, bahwa anak yang belum dewasa dan anak perempuan atau kaum perempuan tidak berhak mendapat warisan dari harta peninggalan orang yang meninggal dunia. Orang-orang pada era pra Islambahkan beranggapan bahwa janda dari orang yang ditinggal mati oleh suaminnya dianggap sebagai warisan yang boleh berpindah tangan dari si ayah kepada anaknya. Artinya di era pra Islam terjadi banyak kecurangan terhadap perempuan dan anak dimana nilai-nilai pewarisan tidak dijalankan sebagaimana mestinya, walaupun keberadaan mereka dibutuhkan.

Dengan demikian Islam sangat menghargai, kaum perempuan maupun kepada para janda, baik kepada anak yang belum dewasa, bahkan anak yang masih dalam kandungan pun tetap di hargai dan di berik haknya, contohnya seorang ibu hamil mendapatkan rukhsah untuk berbuka karena janinya, demikian anak yang sudah lahir tapi masih menyusui juga di berikan rukhsah untuk berbuka karena anak menyusui,demikian dalam hal warisan mereka wajib mendapatkan haknya tanpa membedakan gendernya.

\section{DAFTAR PUSTAKA}

Al Qur'an dan Terjemahannya.

Al Hadits An Nabawi.

Athiyyah Shaqr, Fatawa wa abkam Lil Mar'atil Muslimah, Cairo: Maktabah Wahbah, 2002

Ahmad Umar Hasyim, Al Usrab Fil Islam, Cairo: Al Atlas Al Abbasiyah, 1334 $\mathrm{H} / 2013 \mathrm{M}$

Aunur Rahim Faqih Mawaris, Hukum Waris Islam, Yogyakarta: UII Press, 2017

Dominikus Rato, S.H., M.Si., Hukum Perkawinan dan waris Adat di Indonesia, Sistem kekerabatan, Perkawinan, dan Pewarisan Menurut Hukum Adat, Yogyakarta: Laksbang Pressindo, 2015

Lajnah Min Kulliyah Syariah Jamiatul Azhar, Ahkamul Mawarits Fil Fiqhi Islami, Cairo: Arrislah Addauliyah, Ain Syams, 2015 
M. Athoillah, M.Ag., Fikih Waris (Metode Pembagian Waris Praktis), Bandung: Yrama Widya, 2013

Muhammad Bakri Ismail, Al Fiqhul Wadhi, cetakan II, Jilid II, Cairo: Darul Manar, $1418 \mathrm{H} / 1997 \mathrm{M}$

Muammar M.Bakry, Lc.MA., Akuntansi Dasar Mawaris, Jogyakarta: Ladang Kata, 2015

Muhammad Said Ramadhan Al Bouty, Fiqbu Sirah, Cetakan VII, Beirut:Darul Fikri, $1398 \mathrm{H} / 1987 \mathrm{M}$

Muhammad Ali As Shabuni, Hukum Waris Dalam Islam, Depok: Cetakan Pertama, Senja Publishing, 2015

Muhammad Mutawalli Sya'rawi, Al Mar'atul Fil Qur'an, Akhbarul Youm, Maktabah As Sya'rawil Islamiya, t.t.

----------, 500 Soal Jawab Lil Mar'til Muslimah, Cairo: Al Maktabah At Taufiqiyaah , t.t.

----------, Nasha'ih Lil Mar'til Muslimah, Cairo: Maktabah Taufiqiyyah Lit Thabaa'ah, t.t.

Mohd. Rifa'I, Fiqih Islam, Edisi Yang Disempurnakan, Semarang Indonesia: PT Karya Toha Putra, 2014

Saifuddin Masykuri, Ilmu Faraidl Pembagian Harta Warisan, cetakan Santri Salap Press dan Lirboyo Press, 2016

Sayyid Sabiq, Fiqhu As Sunnah, Cairo: Darul Fath Lil I'lam Arabi, Jilid I, 1414 H$1994 \mathrm{M}$

Sofia Hardani, Perkara Mafqud di Pengadilan Agamad di Provinsi Riau dalam Perspektif Keadilan Gender, Marwab: Jurnal Perempuan, Agama, dan Gender, Vol. 17, No. 2, Desember Th. 2018, http://ejournal.uinsuska.ac.id/index.php/marwah/article/view/4810/3769

Sulaiman Rasjid, Figh Islam, Jakarta: Sinar Baru Algesindo, cetakan ke 66, 2016

Umar, Nasaruddin, Argumen Kesetaraan Gender Perspektif Al-Quran, Jakarta: Paramadina, 1999

Wahiduddin Khan Al Mar'atul baina Syariatil Islami Wal Hadhararatil Gharbiyah, Cairo: Darus Shahwah, 1414 H/1994 M 